\title{
DETERMINANTS OF THE EUROPEAN UNION'S TRADE - EVIDENCE FROM A PANEL ESTIMATION OF THE GRAVITY MODEL
}

\author{
Michał Bernard Pietrzak, Justyna Łapińska
}

\section{Introduction}

In the world's economy the last two decades have been a period of development of regional integration groups. A number of new groups came into being and the already existing ones followed the path of deepening the integration process. The basis of the process is formed by the expectations that integration allows production volume and exports to be increased, and economic resources to be allocated more effectively. According to the integration theory, foreign trade is the area in which the impact of regional integration on a country's economy is most visible and clear. The positive effects in trade evoked by such processes have been noted by abundant empirical research [28], [26], [17], [16], [10].

The intensification of liberalisation processes in trade within regional integration groups results from the lack of satisfactory progress in multilateral commercial negotiations conducted during subsequent GATT/WTO meetings. It is estimated that at present more than a half of international trade occurs within various regional integration groups. Most frequently such groups are composed of countries that share a similar geographical location.

It has been only a few years since the expansion of the European Union. Although this period is relatively short for making an objective assessment of the course of economic processes, we can already observe certain changes and new developmental trends both in individual economies as well as in the whole group. Since the accession of the new EU members, its trade volume has increased. An analysis of the current statistical data clearly shows this. However, a simple indicators analysis shows only changes over time but it neglects the causes of these changes. With a view to learning the causes, the present paper proposes applying a gravity model for the purpose of evaluating the impact of selected factors, mainly economic ones, on the development of bilateral trade in the EU states in the years 1999-2010.

The research applied the gravity model of trade for panel data. GDP per capita, foreign direct investment per capita, and distances between countries were taken as potential determinants. Moreover, we considered the impact of EU membership on the increase in trade volume in both the $15 \mathrm{EU}$ states and the 12 new member states.

\section{Gravity Models of Trade - Subject Literature}

For the first time the gravity model was applied in an analysis of international flows of commodities in the nineteen sixties by a Dutch economist and physicist, Tinbergen [36]. Pöyhönen [30] and Linnemann [25] also joined the precursor group.

By making a reference to Newton's law of universal gravitation, Tinbergen proposed a gravity model of trade in a form described by the following equation

$$
X_{i j}=C \frac{Y_{i}^{\alpha} Y_{j}^{\beta}}{D_{i j}^{\delta}},
$$

where:

$X_{i i f}$ - trade stream between country $i$ and $j$,

$Y_{i}^{\prime \prime}$ - exporting country's gross national product, $Y_{-}$- importing country's gross national product,

$\mathrm{D}_{i j}$ - geographical distance between economic centres (capital cities) of country $i$ and country $j$,

$\alpha, \beta, \delta$ - trade elasticity relative to the exporting country's gross national product, the importing country's gross national product 
and the distance between these two trading countries,

$$
\text { C - gravitational constant. }
$$

The basic equation applied in the evaluation of gravity models of trade is created by the linearisation of equation (1). After making a two-sided logarithm we receive the following equation:

$$
\ln X_{i j}=\ln C+\alpha \ln Y_{i}+\beta \ln Y_{j}-\delta \ln D_{i j}
$$

According to the above equation, the value of the bilateral trade exchange $X_{i j}$ between country $i$ and country $j$ is correlated positively with the economic size of the two countries, expressed by their levels of gross national products $Y_{i}$ and $Y_{j}$, and it is correlated negatively with the distance between them.

While dealing with gravity models of trade, it is essential to determine the variable, which describes 'the strength of mutual influence' of the trading partners, which means a dependent variable (the explained one). This dependent variable may represent exports, imports or the total bilateral exchange being the sum of exports and imports.

The most frequently applied dependent variable is exports [23], [34], [12], [21]. Conducting research with imports as the only variable is very uncommon [15], [24]. An advantage of taking exports as a dependent variable is its lesser deformation resulting from using various protection instruments and the fact that it is taken into consideration in transportation and insurance costs. However, data on exports may be burdened with a certain error. This error is traced back to tax forms filled in by companies, which sometimes for taxation reasons decrease or increase the value of their exports when they receive subsidies.

Total bilateral trade exchange is relatively frequently taken as a dependent variable in empirical studies [5], [37], [9], [22]. Defining a dependent variable in such a way represents, on the one hand, a holistic approach to trade exchange, but, on the other hand, it means facing problems with complete information availability. In fact, both on the exports and imports sides there occurs incomplete information; therefore, considering the two directions of trade may occasionally lead to their cumulation [11].

While constructing a gravity model, it is an important issue to determine which variables will be treated as countries' masses, i.e., what will decide about the strength of an economy's attractiveness, and in what way the distance between trading partners will be described.

Countries' economic value, which functions as an attraction factor, may be measured in a similar way to that proposed by Linnemann [25] - a combination of Gross National Product and the number of citizens. After the publication of Anderson's [3] and Bergstrand's [7] works explaining basic theoretical assumptions of gravity models, the measure most frequently applied in empirical works of trading countries' income is their Gross Domestic Product. For the purpose of a better adjustment of the model to the actualities, many authors frequently consider trading partners' per capita income as an explanatory variable [20], [23], [10], [31]. Empirical research proves that trade volume between developed countries tends to be higher [21].

In Newton's model distance represents the resistance that masses need to overcome on their way to each other, so it functions as a factor diminishing the gravity force. In models of international trade the geographical distance reflects predominantly transport and communication costs, which impact significantly trade exchange volume between trading partners. However, it is not the only factor affecting the intensity of trade exchange between a pair of countries. Another factor relative to the geographical distance is the common border line (or the lack of one) between these countries. Neighbouring countries which share the same border line tend to trade more frequently than those which do not have a common border line [35], [29].

Although somewhat differently, McCallum [27] also applied gravity models to deal with the problem of border lines. While comparing the trade exchange between specific provinces in Canada with the trade exchange between the state of Canada and some US states, he observed the occurrence of a so-called border effect. He proved that the trade exchange between a country's distant parts (regions) reaches a decidedly higher level than between two neighbouring regions from two different countries (sharing a border line). In the case of selected Canadian provinces the trade exchange volume was twenty-fold greater than the trade exchange volume recorded between Canada and the United States.

Other factors that may stimulate or impede a bilateral trade exchange between countries 
are dummy variables describing a common culture, in particular a common language, national identity, tradition or history [13]. Cultural ties due to relatively low barriers to running business activity on foreign markets (the use of the same language facilitates communication), low transaction costs (the ease of transferring information) and a similar demand structure facilitate significantly trading activity [38].

A factor that strengthens bilateral trade exchange is the partners' participation in regional group integration. Market liberalisation, which is an element of integration processes, affects the efficiency of resource allocation in economies [6]. The impact of regional economic integration on resource allocation in an economy is usually analysed by means of the following two effects: trade creation and trade diversion.

The effect of trade creation means creating new trading streams between countries, which form an integration group. This effect results from making use of differences in production costs and from the appearance of new additional impulses for trading between an integration group's members due to unlimited liberalisation of trading with the simultaneous existence of barriers to trading with countries from outside the European Union.

The effect of trade diversion consists in replacing supplies from non-member countries with supplies provided by countries that are members of an integration group and whose competitiveness has increased due to removal of trade barriers.

Gravity models constitute an instrument that is frequently applied in researching the impact on mutual trading of the membership of some countries belonging to the same integration group. Studies of the effects of establishing integration groups usually consist in introducing dummy variables for individual groups into models and estimating their significance. While analysing research outcomes of various studies conducted on groups Greenaway and Milner [17] found that the majority of those studies had shown positive trading effects resulting from the implementation of regionalism processes [1], [8]. However, as pointed out by Baier and Bergstrad [5], recent research into the issue does not confirm explicitly the previous results. Endoh [14] found that the Latin American Free Trade Agreement has exhibited neither trade creation nor trade diversion on trade with Japan.
Similar conclusions were reached by Roberts [32] and Rojid [33]. The former examined the effects of free trade between China and the ASEAN countries, and the latter between the COMESA countries.

\section{Panel Gravity Model for Exports from European Union Member States}

Analysis of the factors that determine bilateral trade exchange of European Union member states includes the panel gravity model. The volume of exports per capita of European Union member states from 1999-2010 was taken as the dependent variable. The research covered 27 countries which were EU member states in 2010. GDP per capita and FDI per capita were considered as potential explanatory values. The value of foreign direct investment for specific member states was aggregated over time and presented as a total of the period 1999-2010. The impact of geographical distances between countries expressed as the number of kilometres between capital cities of trade partners was also taken into account. In addition, the impact of the fact of being an EU member state on the increase in trade volume was examined. The focus was on the answer to the question whether enlarging the European Union has contributed to a significant increase in exports per capita from the new member states (EU-12) to the so-called old member states of the European Union (EU-15) and vice versa. Therefore, dummy variables $E U_{12}, E U_{15}$ were introduced into the model.

The following research hypotheses concerning the trade exchange in European Union member states were the subject of verification:

H1: EU membership impacts significantly the increase in trade volumes between member states.

H2: There exists a positive dependence between the level of economic development of an EU member state measured by its GDP per capita and the volume of its exports per capita.

H3: Foreign direct investments strengthen considerably the export potential of member states. Foreign direct investments contribute rather to increases in exports than to satisfying the internal demand.

H4: There exists a negative dependence between the geographical distance between member states and their trade volume. 
Estimation of the following model for the cross-country analysis in view of the above hypotheses was made

$$
\begin{aligned}
\mathbf{X}_{\mathrm{ijt}} & =\boldsymbol{\beta}_{\mathrm{ij}}+\boldsymbol{\beta}_{\mathrm{t}}+\beta_{1} \mathbf{G D P}_{\mathrm{it}}+\beta_{2} \mathbf{G D P}_{\mathrm{jt}}+\beta_{3} \mathbf{F D I}_{\mathrm{it}}+\beta_{4} \mathbf{F D I}_{\mathrm{jt}} \\
& +\alpha_{1} \mathbf{U E}_{12}+\alpha_{2} \mathbf{U E}_{15}-\gamma \mathbf{d}_{\mathrm{ij}}+\boldsymbol{\varepsilon}_{\mathrm{ijt}}
\end{aligned}
$$

where $\boldsymbol{X}_{i j t}$ is the vector of the dependent variable, $G D P_{i t}, G D P_{j t}, F D I_{i t}, F D I_{j t}, d_{i j}$ are vectors of the explanatory variables, $\boldsymbol{E} \boldsymbol{U}_{12}, \boldsymbol{E} \boldsymbol{U}_{15}$ are vectors of dummy variables that indicate European Union membership, $\boldsymbol{\beta}_{i j}, \boldsymbol{\beta}_{t}$ are vectors of individual and time effects in the panel model, $\boldsymbol{\alpha}_{1}, \boldsymbol{\alpha}_{2}, \boldsymbol{\beta}_{1}, \boldsymbol{\beta}_{2}, \boldsymbol{\beta}_{3^{\prime}}$, $\boldsymbol{\beta}_{4}, \boldsymbol{V}$ are structural parameters of the model, $\boldsymbol{\varepsilon}_{i j t}$ is vector of disturbances. All variables without dummy variables are expressed in logarithms. The description of specific variables and the sources of data used are shown in Table 1 and Table 2.

\begin{tabular}{|c|c|}
\hline Symbol & Description of variables \\
\hline $\mathbf{X}_{\mathrm{ijt}}$ & Exports per capita from country $i$ to country $j$, in the time period $t$ [in millions of Euros] \\
\hline$G D P_{i t}, G D P_{j t}$ & $\begin{array}{l}\text { Gross Domestic Product per capita in an exporting country } i \text { and in an importing } \\
\text { country } j \text {, in the time period } t \text { [in millions of Euros] }\end{array}$ \\
\hline$F D I_{i t}, F D I_{j t}$ & $\begin{array}{l}\text { Foreign direct investment per capita aggregated over time in an exporting country } \\
i \text { and in an importing country } j \text {, in the time period } t \text { [in millions of Euros] }\end{array}$ \\
\hline $\mathrm{EU}_{12}$ & $\begin{array}{l}\text { Dummy variable, it takes the value of } 1 \text { for the new member states, (UE-12) from } \\
\text { the year } 2004 \text { on and the value of } 0 \text { prior to } 2004 \text {. In the case of Romania and } \\
\text { Bulgaria from } 2007 \text { on. }\end{array}$ \\
\hline $\mathrm{EU}_{15}$ & $\begin{array}{l}\text { Dummy variable, it takes the value of } 1 \text { for the old member states, (UE-15) from } \\
\text { the year } 2004 \text { on and the value of } 0 \text { prior to } 2004\end{array}$ \\
\hline $\boldsymbol{d}_{i j}$ & $\begin{array}{l}\text { Geographical distance between capital cities of countries } i \text { and } j \text { [in thousands } \\
\text { of kilometres] }\end{array}$ \\
\hline
\end{tabular}

\section{Tab. 1: Variables used in the analysis of European Union member states' trade volumes}

*The values of the variables were adjusted by inflation (they are real values)

\begin{tabular}{l|l}
\multicolumn{1}{c}{ Tab. 2: Sources of data used in the research } \\
\multicolumn{1}{c}{ Data } & \multicolumn{1}{c}{ Source } \\
\hline Exports & $\begin{array}{l}\text { EUROSTAT } \\
\text { http://epp.eurostat.ec.europa.eu/portal/page/portal/international_trade/ } \\
\text { data/database }\end{array}$ \\
\hline Gross Domestic Product & $\begin{array}{l}\text { EUROSTAT } \\
\text { http://epp.eurostat.ec.europa.eu/portal/page/portal/national_accounts/ } \\
\text { data/database }\end{array}$ \\
\hline Foreign Direct Investment & $\begin{array}{l}\text { UNCTADSTAT } \\
\text { United Nations Conference on Trade and Development } \\
\text { http://unctadstat.unctad.org/ReportFolders/reportFolders.aspx }\end{array}$ \\
\hline $\begin{array}{l}\text { Geographical distance } \\
\text { between capital cities }\end{array}$ & $\begin{array}{l}\text { Centre D'Etudes Prospectives et D'Informations Internationales } \\
\text { http://www.cepii.fr/anglaisgraph/bdd/distances.htm }\end{array}$ \\
\hline Population & $\begin{array}{l}\text { EUROSTAT } \\
\text { http://epp.eurostat.ec.europa.eu/portal/page/portal/population/data/ } \\
\text { database }\end{array}$ \\
\hline
\end{tabular}




\section{Analysis of the Direction and Strength of the Impact of the Factors that Determine the Level of Exports from European Union Member States}

Interpreting the impact of explanatory variables in gravity models is a complex task. It is so since we have to deal with the simultaneous impact of two effects. The first - the push effect - consists in pushing out trading streams in the case of source regions, i.e., exporters, and the second - the pull effect - is the effect of attracting trading streams in the case of target regions, i.e., importers. The statistical significance of a proper structural parameter proves the occurrence of the push effect or of the pull effect. The statistical insignificance of a structural parameter indicates the lack of the impact of factors which, in accordance with the trade theory, determine the trade volume. The sign of the estimate obtained indicates, in turn, the direction of the impact of specific trade determinants.

Based on the possessed data we conducted the Hausman test [18], which indicated the occurrence of a correlation between random errors and explanatory variables. The estimator of a panel model with random effects (RE) is biased and inconsistent and for that reason the estimation of a panel model with fixed effects (FE) is preferred. Therefore, the following three specifications of a panel model were considered: a panel model with individual effects, a panel model with time effects, and a panel model with both individual and time effects. Test $F$ was conducted for further specifications and it indicated only the significance of individual effects. Finally, estimation of a panel model (FE) with individual effects was made.

In order to estimate the parameters of the panel gravity model we applied the HausmanTaylor estimator [19]. The calculations were made with the application of the R-Cran software. The software uses the plm package (major procedures include: $p / m$, pht, pFtest, phtest).

Table 3 presents the results of the estimation performed for a selected specification of a panel model.

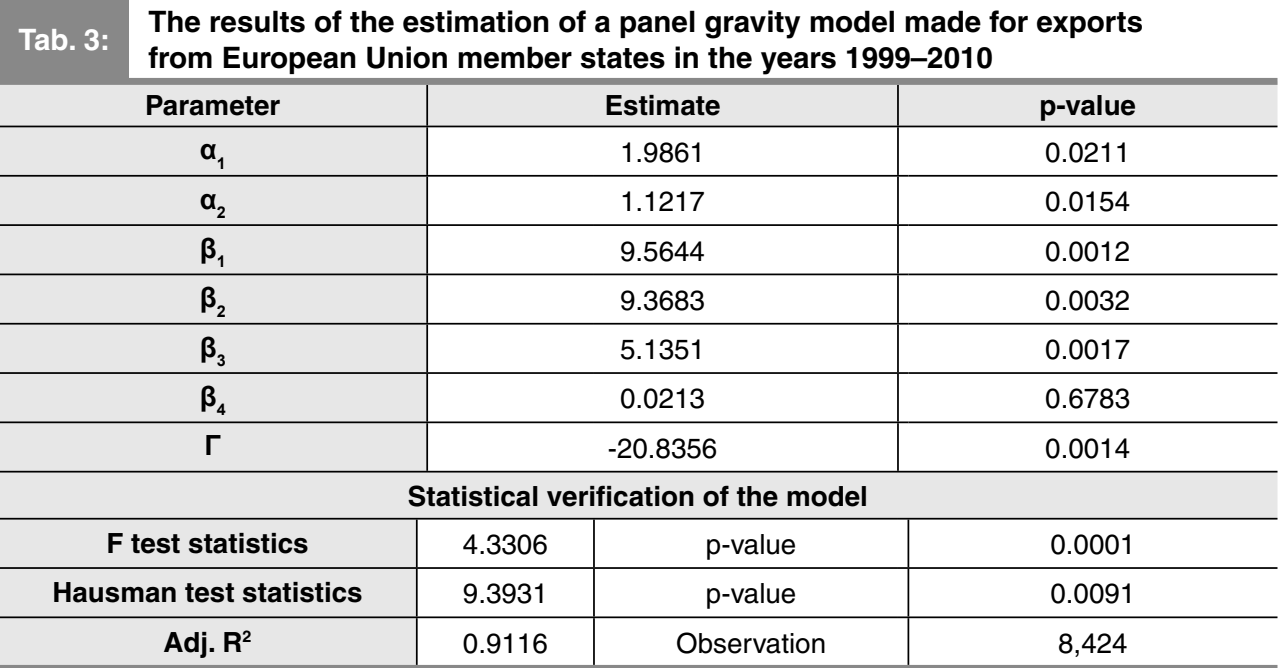

${ }^{*}$ A $5 \%$ significance level was taken for assessing the statistical significance of the parameters.

A significant increase in trade volume between the EU-12 and EU-15 states could be noticed prior to the enlargement of the Community and it resulted from the signing of the Association Agreement. After the formal enlargement of the European Union, however, we could observe a further increase in trade volume between its old member states and the newly accepted states. Parameters $\alpha_{1}$ and $\alpha_{2}$ proved statistically significant. A positive 
estimate of the parameter $\alpha_{1}$ indicates a substantial increase in the level of exports per capita from the 12 new member states to the 15 old EU member states in the period following their accession. A positive estimate of the parameter $\alpha_{2}$ in turn, indicates a considerable increase in the level of exports per capita from the 15 old member states to the 12 new member states of the European Union in the period following the enlargement of the Community. That means that the trade liberalisation hitherto (resulting from association agreements) had not exhausted fully the benefits of the integration. The formal accession of the new EU members was still accompanied by the effect of trade creation since the mutual trade exchange between the EU 15 and the EU 12 was continually increasing. As a matter of fact, the formal enlargement of the European Union did not lead to any major modifications of the customs burden; however, many non-tariff barriers were abolished. As evaluated by The Heritage Foundation, the formal enlargement of the European Union improved significantly the conditions of cooperation between the old EU states and the new ones. That is reflected, among other things, by the indexes of trade freedom, which provide information on the socalled liberalisation from tariffs and non-tariff barriers. The index of trade freedom published in a report by the Index of Economic Freedom is prepared on an annual basis by The Heritage Foundation in cooperation with the Wall Street Journal. The index published for a specific year is based on data and information concerning the previous years and, therefore, most frequently the delay encompasses a three-year period. After the enlargement of the European Union, in the case of the new member states, the trade freedom indexes grew substantially reaching the level represented by the countries which had been EU member states prior to the enlargement of the European Union. The results obtained allowed the verification of the research hypothesis $\mathrm{H} 1$, which focuses on the positive impact of EU membership on the growth of trade exchange. It was proved that after the joining of the Community by the new member states we saw a significant rise in the level of exports from the EU-12 countries to the EU-15 countries and inversely.

When analysing the impact of GDP per capita, which may be identified with a country's level of economic development, it must be stated that the parameters $\beta_{1}$ and $\beta_{2}$ proved statistically significant. Taking into account the positive evaluation of the parameter $\beta$, we may formulate a conclusion that for exporting countries there holds a positive impact of GDP per capita on the level of exports per capita. Also in the case of importing countries the positive evaluation of the parameter $\beta_{2}$ denotes a positive impact of GDP per capita on the level of imports per capita in those countries. Countries with a higher level of economic development, apart from greater importing needs resulting from a good economic situation, also display a larger exporting potential which translates into a higher level of exports, if compared with countries with lower values of GDP per capita. The results obtained allowed us to verify the research hypothesis $\mathrm{H} 2$ on a positive dependence between the level of economic development of an EU member state measured by its GDP per capita and the volume of its exports per capita.

Foreign direct investment belongs to a group of trade determinants which may exert a varied influence on the development of trade volume between countries. On the one hand, the flow of capital in the form of foreign direct investment may lead to a technological modernisation of the economy that is related to the development of industry and manufacture of processed goods, which, in turn, fosters the development of trade. On the other hand, foreign direct investment may be initiated by the willingness to service the host country's market and then it functions as a substitute to trade [2]. In the case of foreign direct investment the parameter $\beta_{3}$ proved statistically significant and the parameter $\beta_{4}$ proved statistically insignificant. The positive value of the parameter $\beta_{3}$ indicates a positive impact of foreign direct investment on the value of exports per capita. The research result allowed the verification of the hypothesis $\mathrm{H} 3$ according to which foreign direct investment strengthens considerably the export potential of member states. The statistically insignificant parameter $\beta_{4}$ indicates the lack of a major impact of foreign direct investments on import volume.

The geographical distance factor is essential for the development of trade exchange. Its impact is mainly related to the costs of transportation and insurance of goods being the subject of exchange. The parameter $\mathrm{\gamma}$, which measures the impact of geographical distances 
between specific countries of the European Union on their bilateral trade exchange, proved statistically significant. A negative estimate corresponds to the theoretical predictions and indicates that trade volume decreases when the geographical distance between countries increases. That finding enabled us to verify the hypothesis $\mathrm{H} 4$ according to which there is a negative dependence between the geographical distance between member states and their trade volumes.

As a result of the estimation of a panel gravity model 8,424 residuals were obtained. Based on the obtained realisations of the disturbances it is possible to conduct an analysis of selected residual values that are untypical values. Untypical values are deemed to be such values whose absolute value exceeds a threefold value of the standard deviation.

Such an analysis enables the identification of the countries whose trade volumes differ considerably from theoretical values that result from the estimated model. For instance, in the case of the trade exchange volumes of Belgium and Luxembourg, both exports and imports in the countries could be higher than implied by the model (positive residuals). That proves a significant role of foreign trade in both countries' economies that is proportionally greater than in the whole of the European Union. In the case of the Bulgarian and Romanian economies, the weakest ones in the European Union, we can observe a reverse situation - the occurrence of negative untypical residual values. In turn, the analysis of residuals conducted for Cyprus, Greece, and Malta, whose GDP is derived mainly from revenues from the tourist industry, indicates a disproportionally high import volume if compared with their exports.

\section{Conclusion}

In recent years the European Union has followed the path of deepening the integration by accepting new member states. The benefits of enlarging the integration group are felt not only by the newly accepted states but also by its old member states. In accordance with the theory, one of the most significant integration effects is growth in mutual trade exchange. The actual development of trade exchange between member states is a vital argument in favour of creating regional integration groups and enlarging them.

The research was focused on finding out whether European Union membership impacts the level of increases in trade volumes between EU member states. The problem was analysed separately for the 15 old member states of the European Union (EU-15) and separately for the new member states (EU-12). The research conducted allowed the formulation of a conclusion that the accession was followed by a significant increase in the level of exports both from the EU-12 countries to the EU-15 countries and inversely. Also, the work evaluated the impact of economic factors such as GDP per capita, foreign direct investment and the geographical distance on the development of bilateral trade exchange of European Union member states. The outcome of the research allowed the formulation of a statement that there is a positive dependence between the level of economic development of an EU member state, measured by means of its GDP per capita and its exports volume per capita. In the case of foreign direct investment, it was found that it improves the export potential of EU member states rather than satisfying the internal demand. Also, the existence of a negative dependence between the geographical distance between member states and their trade volumes was found.

The conclusions formulated in the paper enable us to state that from the perspective of the developmental opportunities the European Union is an entity worth belonging to. The benefits are felt both by the old EU member states and by the new EU member states. The results obtained confirm the relevance of the theories of integration and trade.

\section{References}

[1] AITKEN, N. The Effects of the EEC and EFTA on European Trade: a Temporal Crosssection Analysis. American Economic Review. 1973, Vol. 63, Iss. 5, pp. 881-892. ISSN 00028282.

[2] AMITI, M., GREENAWAY, D., WAKELIN, K. Foreign Direct Investment and Trade: Substitutes or Complements? [online]. University of Melbourne, 2000 [cit. 2013-10-02]. 24 p. (PDF). Available from: http://dev3.cepr. $\mathrm{org} / \mathrm{meets} / \mathrm{wkcn} / 2 / 2290 /$ papers/amiti.pdf.

[3] ANDERSON, J. E. A Theoretical Foundation for the Gravity Equation. American Economic Review. 1979, Vol. 69, Iss. 1, pp. 106-116. ISSN 0002-8282.

[4] BAIER, S. L., BERGSTRAND, J. H. Economic Determinants of Free Trade Agreements. 
Journal of International Economics. 2004, Vol. 64, Iss. 1, pp. 29-63. ISSN 0022-1996. doi:10.1016/S0022-1996(03)00079-5.

[5] BAIER, S. L., BERGSTRAND, J. H. Do free trade agreements actually increase members' international trade? Journal of International Economics. 2007, Vol. 71, Iss. 1, pp. 72-95. ISSN 0022-1996. doi:10.1016/j.jinteco.2006.02.005.

[6] BALDWIN, R. E. Towards an Integrated Europe. London: Centre for Economic Policy Research, 1994. ISBN 978-189-812813-7.

[7] BERGSTRAND, J. H. The Gravity Equation in International Trade: Some Microeconomic Foundations and Empirical Evidence. Review of Economics and Statistics. 1985, Vol. 67, Iss. 3, pp. 474-481. ISSN 0034-6535. doi:10.2307/1925976.

[8] BRADA, J. C., MENDEZ, J. A. Economic integration among developed, developing and centrally planned economies: a comparative analysis. Review of Economics and Statistics. 1985, Vol. 67, Iss. 4, pp. 549-556. ISSN 00346535. doi: $10.2307 / 1924798$.

[9] BUN, M. J. G., KLAASSEN, F. J. G. M. The Euro Effect on Trade is not as Large as Commonly Thought. Oxford Bulletin of Economics and Statistics. 2007, Vol. 69, Iss. 4, pp. 473-496. ISSN 0305-9049. doi:10.1111/ j.1468-0084.2007.00448.x.

[10] CARRĖRE, C. Revisiting the effects of regional trade agreements on trade flows with proper specification of the gravity model. European Economic Review. 2006, Vol. 50, Iss. 2, pp. 223-247. ISSN 0014-2921. doi:10.1016/j. euroecorev.2004.06.001.

[11] CZARNY, E., FOLFAS, P. Modele grawitacji jako narzędzie analityczne $w$ ekonomii międzynarodowej. In: ZIELINSKI, Z. E. (ed.). Rola informatyki w naukach ekonomicznych $i$ społecznych. Innowacje $i$ implikacje interdyscyplinarne. Kielce: Wydawnictwo Wyższej Szkoły Handlowej, 2011. ISBN 97883-89274-65-6.

[12] EGGER, P. An Econometric View on the Estimation of Gravity Models and the Calculation of Trade Potentials. World Economy. 2002, Vol. 25, Iss. 2, pp. 297-312. ISSN 03785920. doi:10.1111/1467-9701.00432.

[13] EICHENGREEN, B., IRWIN, D. A. The Role of History in Bilateral Flows. In: FRANKEL, J. A. (ed.). The Regionalization of the World Economy. Chicago: University of Chicago Press, 1998. ISBN 978-0226260228. doi:10.7208/ chicago/9780226260228.003.0003.
[14] ENDOH, M. Trade creation and trade diversion in the EEC, the LAFTA and the CMEA: 1960-1994. Applied Economics. 1999, Vol. 31, Iss. 2, pp. 207-216. ISSN 0003-6846. doi:10.1080/000368499324435.

[15] FUKAO, K., OKUBO, T., STERN, R. M. An econometric analysis of trade diversion under NAFTA. The North American Journal of Economics and Finance. 2003, Vol. 14, Iss. 1, pp. 3-24. ISSN 1062-9408. doi:10.1016/S10629408(02)00118-3.

[16] GHOSH, S., YAMARIK, S. Are Regional Trading Agreements Trade Creating? An Application of Extreme Bounds Analysis. Journal of International Economics. 2004, Vol. 63, pp. 369-395. ISSN 0022-1996. doi:10.1016/ S0022-1996(03)00058-8.

[17] GREENAWAY, D., MILNER, C. Regionalism and Gravity. Scottish Journal of Political Economy. 2002, Vol. 49, Iss. 5, pp. 574-585. ISSN 0036-9292. doi:10.1111/1467-9485.00249.

[18] HAUSMAN, J. A. Specification Tests in Econometrics. Econometrica. 1978, Vol. 46, Iss. 6, pp. 1251-1271. ISSN 0012-9682.

[19] HAUSMAN, J. A., TAYLOR, W. E. Panel Data and Unobservable Individual Effect. Econometrica. 1981, Vol. 49, Iss. 6, pp. 13771398. ISSN 0012-9682. doi:10.1016/03044076(81)90085-3.

[20] HAVRYLYSHYN, O., PRITCHETT, L. European Trade Patterns After the Transition. Working Paper 748 [online]. The World Bank, 1991 [cit.2013-10-02]. Available form: http://wwwwds.worldbank.org/servlet/WDSContentServer/ WDSP/IB/1991/08/01/000009265_3961001212 040/Rendered/PDF/multiopage.pdf.

[21] HEAD, K. Gravity for Beginners [online]. 2000 [cit. 2013-10-02]. Available from: http:// pacific.commerce.ubc.ca/keith/gravity.pdf.

[22] HENDERSON, D. J., MILLIMET, D. L. Is Gravity Linear? Journal of Applied Econometrics. 2008, Vol. 23, Iss. 2, pp. 137-172. ISSN 0883-7252. doi:10.1002/jae.974.

[23] KALIRAJAN, K. Stochastic Varying Coefficients Gravity Model: An Application in Trade Analysis. Journal of Applied Statistics. 1999, Vol. 26, Iss. 2, pp. 185-193. ISSN 02664763. doi:10.1080/02664769922520.

[24] KANDOGAN, Y. Evidence for the natural trade partners theory from the EuroMediterranean region [online]. University of Michigan, Flint School of Management, 2005 [cit. 2013-10-02]. 35 p. (PDF). Available from: http://som.umflint.edu/yener/2005-01.pdf. 
[25] LINNEMANN, H. An Econometric Study of International Trade Flows. Amsterdam: North Holland Publishing Company, 1966.

[26] ŁAPIŃSKA, J. Determinants of IntraIndustry Trade in Agricultural and Food Products between Poland and EU Countries. DANUBE: Law and Economics Review. 2014, Vol. 5, Iss. 3, pp. 159-172. ISSN 1804-8285. doi:10.2478/ danb-2014-0009.

[27] MCCALLUM, J. National Borders Matter: Canada - U.S. Regional Trade Patterns. American Economic Review. 1995, Vol. 85, Iss. 3, pp. 615-623. ISSN 0002-8282.

[28] NILSSON, L. Trade Integration and the EU Economic Membership Criteria. European Journal of Political Economy. 2000, Vol. 16, pp. 807-827. ISSN 0022-3808. doi:10.1016/S01762680(99)00060-9.

[29] OK, S. T. What Determines Intra-EU Trade? The Gravity Model Revisited. International Research Journal of Finance and Economics. 2010, Vol. 39, pp. 245-250. ISSN 1450-2887.

[30] PÖYHÖNEN, P. A. Tentative Model for the Volume of Trade between Countries. Weltwirtschaftliches Archiv. 1963, Vol. 90, Iss. 1, pp. 93-99. ISSN 0043-2636.

[31] RAHMAN, M. M. Australia's global trade potential: evidence from the gravity model analysis. [online]. Oxford: Oxford University, 2009. [cit. 2013-10-02]. 41 p. (PDF). Available from: http://eprints.usq.edu.au/5537/1/ Rahman_OBEC_09_PV.pdf. ISBN 978-09742114-1-9.

[32] ROBERTS, B. A. A Gravity Study of the Proposed China-ASEAN Free Trade Area. The International Trade Journal. 2004, Vol. 18, Iss. 4, pp. 335-353. ISSN 0885-3908. doi:10.1080/08853900490518208.

[33] ROJID, S. COMESA Trade Potential: a Gravity Approach. Applied Economics Letters. 2006, Vol. 13, pp. 947-951. ISSN 1350-4851. doi:10.1080/13504850500426061.
[34] ROSE, A. K. One Money, One Market? The effects of Common Currencies on International Trade. Applied Economics Letters. 2000, Vol. 15, Iss. 30, pp. 7-46. ISSN 1350-4851. doi:10.3386/ w7432.

[35] SERLENGA, L., SHIN, Y. Gravity Models of the Intra-EU Trade: Application of the HausmanTaylor Estimation in Heterogeneous Panels with Common Time-specific Factors [online]. 2004 [cit. 2013-10-02]. 32 p. (PDF). Available from: http://www.dse.uniba.it/Convegni/incontro_ cnr_2004/Serlenga_gravity.pdf.

[36] TINBERGEN, J. Shaping the World Economy: Suggestions for an International Economic Policy. Periodicals Service Company, 1962. ISBN 978-052-702836-7.

[37] TZOUVELEKAS, V. Accounting for pairwise heterogeneity in bilateral trade flows: stochastic varying coefficient gravity model. Applied Economics Letters. 2007, Vol. 14, Iss. 12, pp. 927-930. ISSN 1350-4851. doi:10.1080/13504850600705919.

[38] ZIELIŃSKA-GŁĘBOCKA, A. Teorie międzynarodowejspecjalizacji wewnątrzgałęziowej ihandlu towarami przemystowymi między krajami uprzemystowionymi. Gdańsk: Wydawnictwo Uniwersytetu Gdańskiego, 1991. ISBN 837017-348-9.

Michał Bernard Pietrzak, Ph.D.

Nicolaus Copernicus University in Torun Faculty of Economics and Management Department of Econometrics and Statistics Michal.Pietrzak@umk.pl

Justyna Łapińska, Ph.D.

Nicolaus Copernicus University in Toruń Faculty of Economics and Management Department of Marketing and Trade justlap@umk.pl 


\section{Abstract}

\section{DETERMINANTS OF THE EUROPEAN UNION'S TRADE - EVIDENCE FROM A PANEL ESTIMATION OF THE GRAVITY MODEL}

\section{Michał Bernard Pietrzak, Justyna Łapińska}

The article is focused on the issue of trade exchange between European Union member states. The trade exchange volume noted an increase after the new members had joined the European Union. That may be observed while analysing statistical data on the trade exchange volume in specific states as well as in the whole of the European Union. A simple index analysis of the trade volume enables researchers to observe changes over time; however, it neglects the causes of these changes. With a view to identifying theses causes, an econometric tool - the panel gravity model - was used for the purposes of the present paper.

The research objective of the paper is to evaluate the impact of selected factors on the development of bilateral trade in the European Union in the years 1999-2010. The group of potential factors describing the size of trade exchange includes the following: the Gross Domestic Product per capita, foreign direct investment per capita and the geographical distance between trading partners.

The research outcome enabled us to draw a conclusion on a positive dependence between a member state's GDP and its export and import volume. In the case of foreign direct investments, their positive impact on the improvement of member states' exporting potential was identified. Moreover, a negative dependence between the geographical distance and the size of their trade exchange was proved. Also, the paper discussed the impact of EU membership on increasing trade exchange volume. The research found an essential increase in exports from the new EU-12 countries to the EU-15 countries and inversely.

Key Words: Trade, gravity model, panel estimation, European Union.

JEL Classification: C33, F14.

DOI: 10.15240/tul/001/2015-1-002 